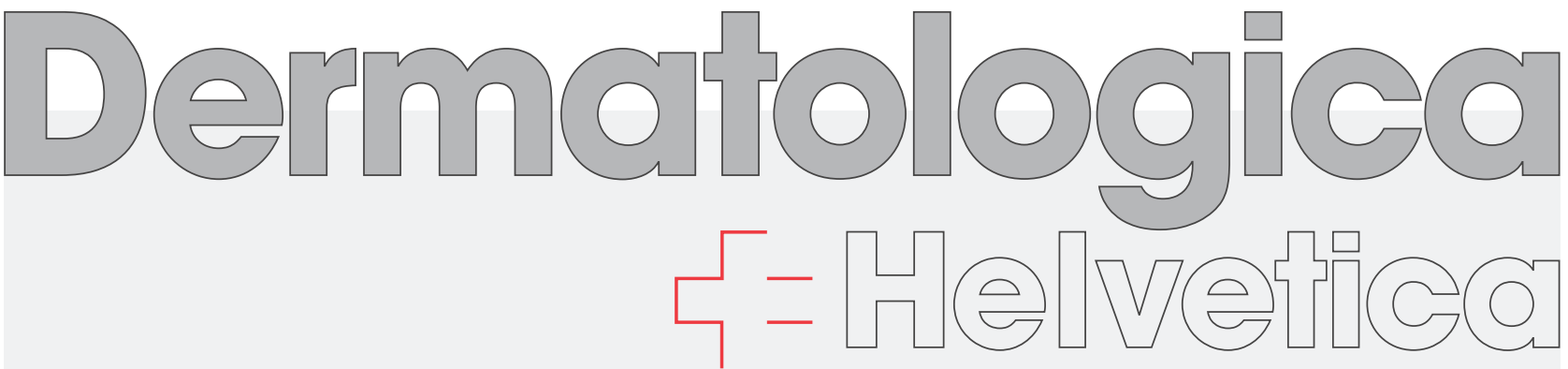

4 Tribune du président de la SSDV Forum des Präsidenten der SGDV

\section{Annonce}

Anzeige

6 Journal-club pour le praticien Journal-Klub für den Praktiker

12 Nouvelles de la SSDV

Neues aus der SGDV

25 Billets d'humour et d'humeur Humorvolles und Launiges

27 Nouvelles de l'industrie Neues aus der Industrie

\title{
Dermatologische Klinik
}

Imiquimod und epitheliale Neoplasien der Haut
Programme de formation continue de la Société Suisse de Dermatologie et Vénéréologie 2005-2007

Ce numéro a été réalisé grâce à une aide pour la formation continue des dermatologistes suisses de la firme:

Dieses Heft wurde für die Fortbildung der Schweizer Dermatologen dank einer Hilfe der folgenden Firma realisiert:

\section{Dermatologica Widmer}

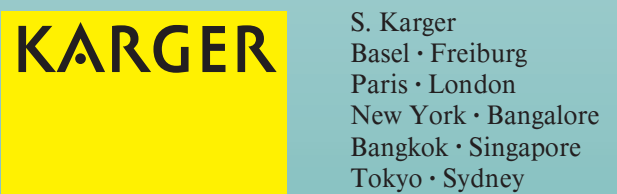

